\title{
PEMBERIAN REMISI TERHADAP NARAPIDANA DI LEMBAGA PEMASYARAKATAN
}

\author{
Umi Enggarsasi dan Atet Sumanto \\ Fakultas Hukum Universitas Wijaya Kusuma Surabaya \\ e-mail: enggarsasi.umi@gmail.com, atet.bbh@yahoo.com
}

\begin{abstract}
ABSTRAK
Remisi merupakan hak narapidana untuk mendapatkan pengurangan pidana apabila selama menjalani pembinaan berkelakuan baik. Remisi yang merupakan hak narapidana dapat ditambah apabila yang bersangkutan melakukan perbuatan-perbuatan antara lain: Berbuat jasa kepada negara, dan Melakukan perbuatan yang bermanfaat bagi negara atau kemanusiaan, serta Melakukan perbuatan yang membantu kegiatan Lembaga Pemasyarakatan. Pengaturan remisi ada dalam beberapa peraturan yaitu: Keputusan Presiden No. 174 Tahun 1999 tentang Remisi; Keputusan Menteri Hukum dan Perundang-undangan RI No. M.09.HN.02.01 Tahun 1999 tentang Pelaksanaan Keputusan Presiden No. 174 Tahun 1999; Keputusan Menteri Hukum dan Perundang-Undangan No. M.10.HN.02.01 Tahun 1999 tentang Pelimpahan Wewenang Pemberian Remisi Khusus; Keputusan Presiden No. 120 Tahun 1995 tentang Ampunan Istimewa; Keputusan Menteri Kehakiman RI No. 04.HN.02.01 Tahun 1988 tentang Tambahan Remisi bagi Narapidana yang Menjadi Donor Organ Tubuh dan Donor Darah; Surat Edaran No. E.PS.0103-15 tanggal 26 Mei 2000 tentang Perubahan Pidana Penjara Seumur Hidup Menjadi Pidana Penjara Sementara; dan Peraturan Pemerintah No. 99 Tahun 2012 tentang Perubahan Kedua atas Peraturan Pemerintah No. 32 Tahun 1999 tentang Syarat dan Tata Cara Pelaksanaan Hak Warga Binaan Pemasyarakatan. Pelaksanaan remisi terhadap narapidana diawali dari permohonan Kepala Lembaga Pemasyarakatan kepada Kepala Kantor Wilayah Kementerian Hukum dan HAM terhadap narapidana yang layak mendapatkan remisi berdasarkan hasil pembinaan terhadap narapidana. Keputusan remisi yang diberikan oleh Kepala Kanwil Hukum dan HAM didasarkan atas laporan Kepala Lembaga pemasyarakatan dan Undang-Undang No. 12 Tahun 1995 tentang Pemasyarakatan dan PP No. 99 Tahun 2012.
\end{abstract}

Kata Kunci: remisi, narapidana, lembaga pemasyarakatan.

\begin{abstract}
Remission is the right of inmates to get a reduction in crime when undergoing training during good behavior. Remission is the right of prisoners could be increased if the relevant deeds among others: Doing services to the state, and doing deeds that are beneficial to the country or humanity, as well as Perform the action that helps the activities Penitentiary. Remission arrangements in some of the rules are: Presidential Decree No. 174 year1999 concerning Remission; Minister of Law and Legislation Decree No. M.09.HN.02.01 year 1999 on the Implementation of Presidential Decree No. 174 of 1999; Minister of Law and Legislation Decree Number M.10.HN.02.01 year 1999 on Delegation of Authority granting Special Remission; Presidential Decree No. 120 year 1995 concerning the Special Forgiveness; Minister of Justice Decree No. 1988 on Additional 04.HN.02.01 Remission for prisoners Become Organ Donors and Blood; Circular Number E.PS.01-03-15 May 26 year 2000 on the Amendment of Criminal Life Imprisonment While Being Criminal Prison; and Government Regulation No. 99 Year 2012 regarding the Second Amendment to Government Regulation No. 32 Year1999 on Conditions and Procedures for the Implementation of the Right prisoners. Implementation of the remission of prisoners begins on the petition the Head of Penitentiary to the Head Office of the Ministry of Justice and Human Rights of prisoners are eligible for remission based on the guidance to the inmates. Decision remissions granted by the Head of Department of Law and Human Rights based on the reports of correctional and Head of the Institute of Law No. 12 Year 1995 on Penal and PP 99 Year 2012.
\end{abstract}

Keywords: remission, prisoners, prison. 


\section{PENDAHULUAN}

Negara mempunyai kewajiban untuk melindungi warga negaranya dan setiap warga negara mempunyai kewajiban untuk mematuhi hukum. Apabila melakukan perbuatan melawan hukum harus mempertanggungjawabkan perbuatannya di hadapan pengadilan yang dapat berimplikasi munculnya status Terpidana, yang dalam perspektif pemasyarakatan disebut Narapidana. Narapidana merupakan warga negara yang terbukti melakukan perbuatan melawan hukum (pidana) dan harus menjalani pidana hilang kemerdekaan di Lembaga Pemasyarakatan (yang selanjutnya disebut Lapas).

Narapidana di dalam menjalani hilang kemerdekaan masih mempunyai hak-hak tertentu sebagaimana diatur dalam Pasal 14 Undang-Undang Noomor 12 Tahun 1995 tentang Pemasyarakatan. Narapidana mempunyai berbagai latar belakang hingga melakukan perbuatan melawan hukum sehingga di dalam menjatuhkan sanksi terhadapnya berbeda dan negara mempunyai kewajiban mengetahui permasalahan tersebut melalui fungsi hakim yang mengadili perkara untuk bisa mencapai tujuannya yaitu keadilan.

Dengan demikian melalui UU No. 12 Tahun 1995 negara mempunyai kewajiban untuk membina narapidana dengan menempatkannya di Lapas dan menyediakan Balai Pemasyarakatan (selanjutnya disebut BAPAS) yang merupakan pranata untuk melaksanakan bimbingan pemasyarakatan. BAPAS merupakan suatu badan penasehat menteri yang bersifat non struktural. Saran atau pertimbangan antara lain berdasarkan keluhan atau pengaduan Warga Binaan Pemasyarakatan.

Hak narapinada yang ada dalam perundangundangan antara lain melakukan ibadah sesuai dengan agama dan kepercayaannya, mendapat perawatan baik perawatan rohani maupun jasmani, mendapatkan pendidikan dan pengajaran, mendapat pelayanan kesehatan dan makanan yang layak, menyampaikan keluhan, mendapatkan bahan bacaan dan mengikuti siaran media massa lainnya yang tidak dilarang, mendapatkan upah atau premi atas pekerjaan yang dilakukan, menerima kunjungan keluarga, penasehat hukum atau orang tertentu lainnya, mendapatkan pengurangan masa pidana (remisi), mendapatkan kesempatan berasimilasi termasuk cuti mengunjungi keluarga, mendapatkan kebebasan bersyarat, mendapatkan cuti menjelang bebas dan mendapatkan hak-hak lain sesuai dengan peraturan perundang-undangan yang berlaku. Mengenai hakhak narapidana tersebut diatur lebih lanjut dengan Peraturan Pemerintah (selanjutnya disebut PP).

Keberadaan PP No. 32 Tahun 1999 tentang Syarat dan Tata Cara Pelaksanaan Hak Warga Binaan Pemasyarakatan, dan perubahannya yang diatur dalam PP No. 28 Tahun 2006 dan PP No. 99 Tahun 2012 untuk pelaksanaan hak narapidana masih belum terpenuhi semua sehingga menjadi kendala dalam pelaksanaannya. Pembinaan dan pembimbingan narapidana diselenggarakan oleh Menteri dan dilaksanakan oleh Petugas Pemasyarakatan, sebagaimana diatur dalam UU No. 12 Tahun 1995 tentang Pemasyarakatan merupakan pejabat fungsional penegak hukum yang melaksanakan tugas di bidang pembinaan, pengawasan dan pembimbingan Warga Binaan Pemasyarakatan.

Penyelenggaraan pembinaan, pembimbingan Warga Binaan Pemasyarakatan, Menteri dapat bekerjasama dengan instansi pemerintah terkait, badan-badan kemasyarakatan lainnya, atau perorangan yang kegiatannya seiring dengan sistem pemasyarakatan sebagaimana diatur lebih lanjut dalam PP. Untuk pelaksanaan pembinaan di Lapas berdasarkan Pasal 20 UU No. 12 Tahun 1995 dilakukan penggolongan narapidana berdasarkan: Umur, Jenis kelamin, Lama pidana yang dijatuhkan, dan Jenis kejahatan, serta Kriteria lainnya sesuai dengan kebutuhan atau perkembangan pembinaan.

Narapidana sebagai Warga Binaan menjalani pembinaan di Lapas berdasar PP No. 31 Tahun 1999 tentang Pembinaan dan Pembimbingan Warga Binaan Pemasyarakatan, dan pelaksanaannya dilakukan oleh Petugas Pemasyarakatan yang terdiri atas: Pembinaan Pemasyarakatan; Pengaman Pemasyarakatan; serta Pembimbing Kemasyarakatan.

Dalam melaksanakan pembinaan terhadap narapidana Kepala Lapas menetapkan Petugas Pemasyarakatan sebagai Wali Narapidana. Untuk syarat dan tata cara pelaksanaan hak narapidana diatur dalam PP No. 32 Tahun 1999 tentang Syarat dan Tata Cara Pelaksanaan Hak Warga Binaan Pemasyarakatan yang telah dilakukan dua kali perubahan dengan PP No. 28 Tahun 2006 dan PP No. 99 Tahun 2012. Di dalam PP tersebut mengatur tentang pelaksanaan ibadah, perawatan rohani dan perawatan jasmani, pendidikan dan pengajaran, pelayanan kesehatan, 
dan menyampaikan keluhan, adanya bahan bacaan di Lapas, dan lain-lain.

Narapidana dengan berbagai macam tindak pidana yang telah dilakukan antara lain: Tindak pidana narkotika; Tindak pidana perlindungan anak; Tindak pidana psikotropika; Tindak pidana perdagangan anak; Tindak pidana kesehatan; dan lain-lain. Permohonan remisi berdasarkan perilaku narapidana di Lapas sesuai permohonan Kepala Lapas ke Kantor Wilayah Hukum dan Hak Asasi Manusia.

\section{PERUMUSAN MASALAH}

Berdasarkan latar belakang masalah tersebut dapat dirumuskan permasalahan yaitu bagaimana pengaturan dan pelaksanaan remisi terhadap narapidana di Lapas berdasarkan Keputusan Presiden Nomor 174 Tahun 1999 dan Peraturan lainnya.

\section{METODE PENELITIAN}

Penelitian ini menggunakan pendekatan yuridis normatif, yaitu mengkaji masalah berdasarkan peraturan perundang-undangan yang berlaku mengenai remisi. Penelitian ini merupakan penelitian deskriptif dan metode pengumpulan data untuk saling mendukung dari studi kepustakaan dan pengamatan. Analisa data dilakukan secara induktif yang mengkaitkan hasil pengamatan dengan peraturan perundang-undangan.

\section{PEMBAHASAN}

Pengaturan Remisi Berdasarkan Keputusan Presiden Nomor 174 Tahun 1999 dan Peraturan Lainnya

Departemen Hukum dan Hak Asasi Manusia (selanjutnya disebut HAM) sebagai payung sistem pemasyarakatan Indonesia, menyelenggarakan sistem pemasyarakatan agar narapidana dapat memperbaiki diri dan tidak mengulangi tindak pidana, sehingga narapidana dapat diterima kembali dalam lingkungan masyarakatnya, kembali aktif berperan dalam pembangunan serta hidup secara wajar sebagai seorang warga negara.

Peran serta pembinaan narapidana tidak lepas dari Lapas. Pelaksanaan remisi di Indonesia berdasarkan: 1. Keppres No. 120 Tahun 1995 tentang Ampunan Istimewa; 2. Keppres No. 174 Tahun 1999 tentang Remisi; 3. Keputusan Menteri Hukum dan PerundangUndangan No. M.09.HN.02.01 Tahun 1999 tentang Pelaksanaan Keppres No. 174 Tahun 1999; 4.
Keputusan Menteri Hukum dan Perundang-Undangan No. M.10.HN.02.01 Tahun 1999 tentang Pelimpahan Wewenang Pemberian Remisi Khusus; 5. Keputusan Menteri Kehakiman No. 04.HN.02.01 Tahun 1988 tentang Tambahan Remisi bagi Narapidana yang menjadi Donor Organ Tubuh dan Donor Darah; dan 6. Surat Edaran Nomor E.PS.01-03-15 tanggal 26 Mei 2000 tentang Perubahan Pidana Penjara Seumur Hidup Menjadi Pidana Penjara Sementara.

Berdasarkan ketentuan Pasal 2 dan Pasal 3 Keppres No. 174 Tahun 1999 tentang Remisi, ada beberapa jenis Remisi, yaitu: Pertama, Remisi Umum, adalah remisi yang diberikan pada hari peringatan Proklamasi Kemerdekaan Republik Indonesia tanggal 17 Agustus. Kedua, Remisi Khusus, adalah remisi yang diberikan pada hari besar keagamaan yang dianut oleh narapidana dan anak pidana yang bersangkutan dengan ketentuan jika suatu agama mempunyai lebih dari satu hari besar keagamaan dalam setahun, maka yang dipilih adalah hari besar yang paling dimuliakan oleh penganut agama yang bersangkutan. Berdasarkan Keputusan Menteri Hukum dan Perundang-undangan No. M.09. HN.02.01 Tahun 1999 tentang Pelaksanaan Keppres No. 174 Tahun 1999, Pasal 3 ayat (2) menegaskan bahwa pemberian remisi khusus dilaksanakan pada: setiap hari raya Idul Fitri bagi narapidana dan anak pidana yang beragama Islam, setiap hari Natal bagi narapidana dan anak pidana yang beragama Kristen, dan setiap hari raya Nyepi bagi narapidana dan anak pidana yang beragama Hindu, serta setiap hari raya Waisak bagi narapidana dan anak pidana yang beragama Budha. Ketiga, Remisi Tambahan diberikan apabila narapidana atau anak pidana yang selama menjalani pidana telah: berbuat jasa kepada negara; dan melakukan perbuatan yang bermanfaat bagi negara atau kemanusiaan; serta melakukan perbuatan yang membantu kegiatan pembinaan di Lapas.

\section{Remisi Umum dan Remisi Khusus: Sebuah Suplemen}

Menutup akhir tahun 1999 dan mengawali tahun 2000, Pemerintah Republik Indonesia membuat kejutan besar dalam proses pembinaan narapidana dengan memberikan remisi khusus kepada narapidana atau anak pidana melalui Keppres No. 174 Tahun 1999 tentang Remisi yang ketentuan pelaksanaannya dituangkan dalam Keputusan Menteri Hukum dan Perundang-undangan Nomor M.09.HN.02.01 Tahun 
1999 tentang Pelaksanaan Keputusan Presiden RI Nomor 174 Tahun 1999.

Remisi khusus bagi narapidana atau anak pidana yang diberikan berdasarkan pertimbangan bahwa selain remisi merupakan salah satu sarana hukum yang penting dalam rangka mewujudkan tujuan sistem pemasyarakatan juga karena negara Indonesia menjamin kemerdekaan setiap penduduk untuk memeluk agamanya masing-masing, termasuk narapidana.

Dengan dikeluarkannya Keppres No. 174 Tahun 1999 tentang Remisi, maka Indonesia mengenal dua jenis remisi. Pertama, remisi umum yang diberikan pada setiap peringatan Hari Kemerdekaan Negara Republik Indonesia tanggal 17 Agustus. Kedua, remisi khusus yang diberikan pada setiap hari besar keagamaan sesuai dengan agama yang dianut oleh narapidana atau anak pidana yang bersangkutan.

Berdasarkan Keppres No. 174 Tahun 1999 tentang Remisi, ada beberapa ketentuan penting yang patut dicermati dalam pemberian remisi khusus. Diantaranya, diatur bahwa remisi khusus diberikan pada hari besar keagamaan sesuai agama yang dianut oleh narapidana atau anak pidana yang bersangkutan, dengan ketentuan jika suatu agama mempunyai lebih dari satu hari besar keagamaan dalam setahun, maka yang dipilih adalah hari besar yang paling dimuliakan oleh penganut agama yang bersangkutan. Sedangkan besarnya remisi khusus yang diberikan adalah 15 (lima belas) hari bagi narapidana atau anak pidana yang telah menjalani pidana selama enam sampai dua belas bulan, satu bulan bagi yang telah menjalani pidana selama dua belas bulan atau lebih, dan pada tahun pertama, kedua, dan ketiga masing-masing diberikan satu bulan, serta pada tahun keempat dan kelima masing-masing diberikan satu bulan lima belas hari. Sedangkan pada tahun keenam dan seterusnya diberikan remisi dua bulan setiap tahun. Sebagai dasar penghitungan besarnya remisi dihitung sejak tanggal penahanan sampai dengan hari besar keagamaan yang dianutnya, didasarkan pada agama narapidana atau anak pidana yang pertama kali tercatat dalam Buku Register Lapas.

Selain itu dalam Keppres No. 174 Tahun 1999 diatur perubahan pidana penjara seumur hidup menjadi pidana penjara sementara apabila narapidana yang bersangkutan telah menjalani pidana paling sedikit lima tahun berturut-turut serta berkelakuan baik. Jika sebelumnya permohonan perubahan pidana penjara seumur hidup menjadi pidana penjara sementara diajukan melalui Kejaksaan Negeri setempat dan Mahkamah Agung, maka berdasarkan Keppres No. 174 Tahun 1999 permohonan tersebut diajukan langsung kepada Presiden melalui Menteri Kehakiman dan Hak Asasi Manusia RI (atau sekarang Menteri Hukum dan Hak Asasi Manusia RI).

\section{Pelaksanaan Pemberian Remisi terhadap Narapidana di Lapas}

Untuk mewujudkan visi dan misi bangsa Indonesia sesuai dengan UUD 1945 maka pelaksanaannya remisi berdasarkan UUD 1945, Undang-Undang No. 12 Tahun 1995 tentang Pemasyarakatan yang kemudian diatur lebih lanjut dalam PP No. 32 Tahun 1999 dan PP No. 28 Tahun 2006 tentang Syarat dan Tata Cara Pelaksanaan Hak Warga Binaan Pemasyarakatan serta Keppres No. 174 Tahun 1999 tentang Remisi.

Dengan banyaknya macam-macam remisi, hal ini merupakan kelonggaran yang cukup banyak oleh pemerintah kepada narapidana untuk selalu memperbaiki sikap tingkah laku dan perbuatannya khususnya di dalam Lapas, sehingga akan memperoleh kemudahan untuk diberikannya remisi. berbagai kesempatan diperoleh narapidana yang berkeinginan sungguh-sungguh akan berbuat baik di dalam kehidupan masyarakat nanti. Namun apabila keinginan untuk mendapatkan remisi hanya sekedar untuk bisa semakin cepat keluar dari Lapas tanpa hasrat untuk memperbaiki perbuatannya di masyarakat nanti maka, tentu ini bukan merupakan cita-cita dari sistem pemasyarakatan yang diterapkan di dalam pembinaan narapidana, sehingga kesempatan yang diberikan itu menjadi sia-sia saja.

Remisi diberikan oleh Menkumham berdasarkan Pasal 1 ayat (2) Keppres No. 174 Tahun 1999 menegaskan bahwa Menteri dapat mendelegasikannya kepada Kantor Wilayah. Penetapan pemberian remisi tersebut dilaksanakan dengan keputusan Kepala Kantor Wilayah atas nama Menteri; sedangkan pada Pasal 2 ayat (2) menegaskan bahwa, segera setelah mengeluarkan penetapan tentang remisi, Kepala Kantor Wilayah wajib menyampaikan laporan tentang penetapan pengurangan masa pidana kepada Menteri melalui Direktur Jenderal Pemasyarakatan. Pemberian remisi khusus hari raya keagamaan dapat dilimpahkan kepada Lapas, Kepala Rumah Tahana Negara, dan Kepala Cabang Rumah Tahanan Negara. 
Adanya pemberian wewenang kepada pejabat yang lebih bawah, berarti mengurangi kepanjangan birokrasi yang sering dialami Negara RI, karena kalau tidak demikian tentu akan memakan waktu yang panjang dan bertambahnya biaya baik tranportasi maupun administrasi yang lain. Dengan diberikannya kekuasaan kepada instansi yang lebih bawah, maka mumpunyai kekuasaan dalam menentukan remisi, disinilah akan banyak kedapatan pelanggaran yang sering menyalahgunakan kekuasaan dan jabatan bermain dengan uang atau membayar para petugas Lapas agar diberikan pemotongan masa pidana.

\section{Narapidana yang Tidak Berhak Mendapatkan Remisi}

Berdasarkan Keputusan Presiden RI No. 174 Tahun 1999 Pasal 7, narapidana yang tidak mendapatkan hak diberikannya remisi ialah narapidana yang: a. dipidana dengan pidana hukuman mati atau pidana penjara seumur hidup; b. dipidana kurang dari 6 bulan; c. dikenakan hukuman disiplin dan didaftar pada buku pelanggaran tata tertib Lapas dalam kurung waktu yang diperhitungkan pada pemberian remisi; d. sedang menjalani cuti menjelang bebas; e. dijatuhi pidana kurungan sebagai pengganti pidana denda; f. narapidana kambuhan (residivis), yaitu mantan narapidana yang melakukan tindak pidana lagi dalam kurung waktu 2 (dua) tahun setelah melakukan tindak pidana yang pernah dilakukan.

Khusus untuk narapidana kambuhan (residivis) yang pernah mendapatkan remisi, tidak diberi remisi lagi sampai selesai menjalani sisa pidananya, adanya batasan-batasan untuk dapat atau tidaknya narapidana diberikan remisi itu merupakan sebagai sarana pendidikan yang diterapkan di dalam sistem pembinaan di Lapas, yang harus dipertanggungjawabkan kepada negara dan masyarakat, syarat yang terlalu mudah untuk dapat diberikannya remisi pasti akan disorot oleh masyarakat penerima narapidana itu kembali. dan kalau terlalu berat juga akan mematikan hak narapidana untuk mendapatkan pendidikan atau pembinaan agar mereka yang punya keinginan betulbetul keluar dari Lapas akan dapat diwujudkan.

Apabila dilihat dari syarat-syarat untuk dapat diberikannya remisi, bukanlah syarat yang berat bagi narapidana, asal para narapidana betul-betul menyadari dengan penuh keinsyafan bahwa mereka tinggal di dalam Lapas itu adalah sebagaimana semestinya yang harus dilaluinya sebagi konsekuensi atas perbuatan atau tindakan yang dulu pernah merugikan orang lain. Setelah masa itu lewat pasti mereka akan kembali ke masyarakat luas dengan resiko baik buruk yang akan ditanggung. Apabila perbuatannya nanti baik maka akan diterima baik pula oleh masyarakat, namun apabila perbuatannya tidak baik atau mengulangi lagi perbuatannya maka mereka juga pasti akan dijauhi dan menjadi sasaran untuk diwaspadai.

\section{Tata Cara Pengusulan Pemberian Remisi}

Remisi diusulkan oleh Kepala Lapas kepada Menteri melalui Kepala Kantor Wilayah, pengusulan itu didasarkan atas pertimbangan dari Tim Pengamat Pemasyarakatan (TPP) yang ada di Lapas yang bersangkutan yang terdiri dari beberapa orang untuk menilai perilaku dan perbuatan narapidana atau anak pidana selama menjalani pembinaan di bawah bimbingannya dan dinyatakan telah berkelakuan baik.

Untuk pengusulan remisi, diperlukan kelengkapan administrasi yang diperlukan untuk pemberian atau pengajuan remisi. Ada beberapa formulir yang dipakai disesuaikan dengan remisi yang diajukan, yaitu: pertama. Formulir RU I, dipakai untuk pengusulan remisi umum sebagian; kedua. Formulir RU II, dipakai untuk pengusulan remisi umum seluruhnya; ketiga. Formulir RT I, dipakai untuk pengusulan remisi tambahan sebagian; keempat. Formulir RT II, dipakai untuk pengusulan remisi tambahan seluruhnya; kelima. Formulir RK I, dipakai untuk pengusulan remisi khusus sebagian; keenam. Formulir RK II, di pakai untuk pengusulan remisi khusus seluruhnya.

Pengajuan usulan dengan jenis-jenis formulir itu ditandatangani oleh Kepala Lapas, selanjutnya disampaikan ke Menkumham melalui Kantor Wilayah.

\section{Prosedur Pemberian Remisi}

Pertama, Remisi Umum. Besarnya remisi umum adalah: 1 (satu) bulan bagi narapidana dan anak pidana yang telah menjalani pidana selama 6 (enam) sampai 12 (dua belas) bulan; dan (dua) bulan bagi narapidana dan anak pidana yang telah menjalani pidana selama 12 (dua belas) bulan atau lebih. Pemberian remisi umum dilaksanakan sebagai berikut: a. pada tahun pertama diberikan remisi sebagaimana dimaksud dalam ayat (1); b. pada tahun kedua diberikan remisi 3 (tiga) bulan; c. pada tahun ketiga diberikan remisi 
4 (empat) bulan; d. pada tahun keempat dan kelima masing-masing diberikan 5 (lima) bulan; dan e. pada tahun keenam dan seterusnya diberikan remisi 6 (enam) bulan setiap tahun. Pemberian remisi umum dilaksanakan pada hari Proklamasi Kemerdekaan Republik Indonesia tanggal 17 Agustus.

Kedua, Remisi Khusus. Besarnya remisi khusus adalah: 15 (lima belas) hari bagi narapidana dan anak pidana yang telah menjalani pidana selama 6 (enam) sampai 12 (dua belas) bulan; dan 1 (satu) bulan bagi narapidana dan anak pidana yang telah menjalani pidana selama 12 (dua belas) bulan atau lebih. Pemberian remisi khusus dilaksanakan sebagai berikut: a. Pada tahun pertama diberikan remisi sebagaimana dimaksud dalam Keppres No. 174 Tahun 1999 Tahun 1999 Pasal 4 ayat (1); b. pada tahun kedua dan ketiga masing-masing diberikan remisi 1 (satu) bulan; c. pada tahun keempat dan kelima masing-masing diberikan remisi 1 (satu) bulan sampai 15 (lima belas) hari; dan pada tahun keenam dan seterusnya diberikan remisi 2 (dua) bulan setiap tahun. Pemberian remisi khusus dilaksanakan pada: a. setiap hari raya Idul Fitri bagi narapidana dan anak pidana yang beragama Islam; b. setiap hari Natal bagi narapidana dan anak pidana yang beragama Kristen; c. setiap hari raya Nyepi bagi narapidana dan anak pidana yang beragama Hindu; d. setiap hari raya Waisak bagi narapidana dan anak pidana yang beragama Budha. Apabila selama menjalani pidana, narapidana atau anak pidana pindah agama, maka remisi diberikan kepadanya menurut agama yang dianut pada saat dilakukan pendataan pertama kali.

Ketiga, Remisi Tambahan. Remisi yang diberikan apabila narapidana atau anak pidana yang bersangkutan selama menjalani pidana, berbuat jasa kepada negara, melakukan perbuatan yang bermanfaat bagi negara atau kemanusiaan, atau melakukan perbuatan yang membantu kegiatan pembinaan di Lapas. Besarnya remisi tambahan adalah: 1/2 (satu per dua) dari remisi umum yang diperoleh pada tahun yang bersangkutan bagi narapidana dan anak pidana yang berbuat jasa kepada negara atau melakukan perbuatan yang bermanfaat bagi negara atau kemanusiaan; dan 1/3 (satu per tiga) dari remisi umum yang diperoleh pada tahun yang bersangkutan bagi narapidana dan anak pidana yang melakukan perbuatan yang membantu kegiatan pembinaan di Lapas sebagai pemuka.

Remisi tambahan bagi narapidana yang menjadi donor organ tubuh dan donor darah, berdasarkan
Keputusan Menteri Kehakiman RI No. 04.HN.02.01 Tahun 1998 tanggal 14 Mei 1988 tentang Tambahan Remisi bagi Narapidana yang Menjadi Donor Organ Tubuh dan Donor Darah, Pasal 2 menegaskan bahwa setiap narapidana yang menjalani pidana sementara baik pidana penjara, pidana kurungan maupun pidana pengganti denda dapat diusulkan untuk mendapatkan tambahan remisi apabila menjadi donor organ tubuh dan/atau darah. Sebagai catatan, berdasarkan ketentuan Pasal 12 huruf d Keppres No. 174 Tahun 1999 tentang Remisi, untuk pidana kurungan pengganti pidana denda tidak dapat diberikan remisi tambahan. Pengusulan tambahan remisi tersebut harus disertai tanda bukti/surat keterangan yang sah yang dikeluarkan oleh rumah sakit yang melaksanakan operasi donor organ tubuh, atau oleh Palang Merah Indonesia yang melaksanakan pengambilan darah. Apabila pengusulan tambahan remisi tidak disertai tanda bukti/surat keterangan, maka akan ditolak.

Remisi sebagaimana dimaksud di atas tidak diberikan kepada narapidana dan anak pidana yang: a. dipidana kurang dari 6 (enam) bulan; $b$. dikenakan hukuman disiplin dan didaftar pada buku pelanggaran tata tertib Lapas dalam kurun waktu yang diperhitungkan pada pemberian remisi; c. sedang menjalani cuti menjelang bebas; atau d. dijatuhi pidana kurungan sebagai pengganti denda.

Remisi tambahan diberikan apabila narapidana atau anak pidana selama menjalani pemidanaan memenuhi kriteria: a. berbuat jasa kepada negara; b. melakukan perbuatan yang bermanfaat bagi negara atau kemanusiaan; c. melakukan perbuatan yang membantu kegiatan pembinaan di Lapas. ${ }^{1}$

Prosedur pengajuan remisi diajukan ke Menteri Hukum dan Hak Asasi Manusia oleh Kepala Lapas, Kepala Rumah Tahanan Negara, atau Kepala Cabang Rumah Tahanan Negara melalui Kepala Kantor Wilayah Kementerian Hukum dan Hak Asasi Manusia. Keputusan Menkumham tentang remisi diberitahukan kepada narapidana dan anak pidana pada hari peringatan Proklamasi Kemerdekaan Republik Indonesia tanggal 17 Agustus, bagi narapidana yang diberikan remisi pada hari peringatan Proklamasi Kemerdekaan atau pada hari besar keagamaan yang dianut oleh narapidana dan anak pidana yang bersangkutan. Jika terdapat keraguan tentang hari besar keagamaan yang dianut oleh narapidana atau

\footnotetext{
${ }^{1}$ Dwija Priyanto, Sistem Pelaksanaan Pidana Penjara di Indonesia, Refika Aditama, Bandung, 2006, h. 135-136.
} 
anak pidana, Menkumham berkonsultasi dengan Menteri Agama. Metode pencatatan remisi harus didasarkan pada bentuk atau jenis remisinya dan dicatat dalam daftar tersendiri.

Keempat, Remisi Dasawarsa. Remisi dasawarsa diberikan bertepatan dengan ulang tahun kemerdekaan Indonesia tanggal 17 Agustus, tiap sepuluh tahun sekali. Untuk tahun 2005, bertepatan dengan hari ulang tahun kemerdekaan Republik Indonesia yang keenam puluh tahun. Maka pada tahun tersebut akan diberikan remisi dasarwasa.

\section{Perhitungan Waktu Pemberian Remisi}

Pemberian remisi dihitung sejak masa tahanan Pasal 14 Keppres No. 174 Tahun 1999, kondisi penghitungan pemberian remisi yang dimulai dari masa tahanan ini sangatlah menguntungkan bagi narapidana, narapidana tidaklah dirugikan karena tindakan penahanan yang dilakukan atas dirinya.

Pertama, Besarnya Remisi Umum. Menurut ketentuan Pasal 4 ayat (1) Keppres No. 174 Tahun 1999 adalah: a. satu bulan bagi narapidana atau anak pidana yang telah menjalani pidana selama enam bulan sampai dua belas bulan; b. dua bulan bagi narapidana atau anak pidana yang telah menjalani pidana selama dua belas bulan atau lebih.

Pelaksanaan pemberian remisi umum menurut ketentuan Surat Edaran Direktur Jenderal Pemasyarakatan Nomor EP.01.04-03.2001 adalah: a. pada tahun pertama diberikan remisi sebagaimana dimaksud dalam Pasal 4 ayat (1) Keppres No. 174 Tahun 1999; b. pada tahun ke-2 (dua) diberikan remisi 3 (tiga) bulan; c. pada tahun ke-3 (tiga) diberikan remisi 4 (empat) bulan; d. pada tahun ke-4 dan 5 masing masing diberikan remisi lima bulan; e. pada tahun ke-6 dan seterusnya diberikan remisi 6 bulan.

Kedua, Remisi Khusus. Besarnya pemberian remisi khusus menurut ketentuan Pasal 5 ayat 1 Keppres No. 174 Tahun 1999 adalah: 15 hari bagi narapidana atau anak pidana yang telah menjalani pidana selama 6 sampai 12 bulan, dan 1 (satu) bulan bagi narapidana atau anak pidana yang telah menjalani pidana selama 12 bulan atau lebih.

Pelaksanaan pemberian remisi khusus menurut Surat Edaran Nomor 01.04-03.2001 adalah sebagai berikut: a. pada tahun pertama, diberikan remisi sebagaimana dimaksud Pasal 5 ayat 1 Keppres No. 174 tahun 1999; b. pada tahun ke-2 dan ke-3, masing masing diberikan remisi satu bulan; c. pada tahun ke-4 dan ke-5 masing masing diberikan remisi 1 bulan 15 hari; d. pada tahun ke-6 dan seterusnya diberikan remisi 2 bulan setiap tahunnya.

Ketiga, Remisi Tambahan dan Jenis Remisi yang Lain. Besarnya pemberian remisi tambahan menurut ketentuan Pasal 6 Keppres No. 174 Tahun 1999 adalah 1/2 (satu per dua) dari remisi umum yang diperoleh pada tahun yang bersangkutan bagi Narapidana dan Anak Pidana yang berbuat jasa kepada negara atau melakukan perbuatan yang bermanfaat bagi negara atau kemanusiaan; dan 1/3 (satu per tiga) dari remisi umum yang diperoleh pada tahun yang bersangkutan bagi Narapidana dan Anak Pidana yang telah melakukan perbuatan yang membantu kegiatan pembinaan di Lapas sebagai pemuka.

Melihat persyaratan tersebut di atas, ternyata hal itu lebih memberi kesempatan kepada narapidana untuk selalu berbuat baik selama menjalani masa pidananya. Menurut petugas atau pembimbing Warga Binaan (Narapidana Lapas), memang pelanggaran disiplin tidak banyak dilakukan oleh narapidana, karena pelanggaran itu akan menghilangkan haknya untuk mendapatkan remisi baginya pada tahun itu.

\section{Akibat-akibat Hukum Diberikannya Remisi}

Beberapa akibat hukum pemberian remisi sebagaimana diatur dalam Keppres No. 174 Tahun 1999, dapat dikemukakan sebagai berikut: Pertama, Pengurangan masa pidana yang dijalani narapidana atau anak pidana; Kedua, Pemberian remisi mengakibatkan berkurangnya masa pidana yang masih harus dijalani oleh narapidana; Ketiga, Pengurangan masa pidana yang menyebabkan pembebasan seketika; dan Keempat, Pembebasan diberikan kepada narapidana yang setelah dikurangi remisi umum maupun remisi tambahan, masa pidana yang harus dijalani ternyata mengakibatkan masa pidananya habis, tepat pada saat pemberian remisi yaitu pada tanggal 17 Agustus; Kelima, Masa pembebasan atau pelepasan bersyarat menjadi lebih singkat. Pembebasan bersyarat diberikan kepada narapidana yang telah menjalani masa pidananya selama 2/3, sekurang-kurangnya telah menjalani pidananya selama 9 (sembilan) bulan. Maka dengan pemberian remisi akan mengurangi masa pidana dari narapidana yang bersangkutan, hal ini akan mengakibatkan masa pembebasan bersyarat jadi lebih singkat; Keenam, Akibat hukum lainnya adalah remisi yang didalamnya mengatur pula ketentuan 
tentang komutasi atau perubahan pidana penjara seumur hidup menjadi pidana sementara waktu 15 tahun, dengan syarat antara lain narapidana tersebut telah menjalani pidana paling sedikit 5 (lima) tahun berturut-turut dan berkelakuan baik.

\section{PENUTUP}

\section{Kesimpulan}

Berdasarkan hasil penelitian dapat disimpulkan pengaturan dan pelaksanaan pemberian remisi terhadap narapidana di Indonesia berdasarkan: Keputusan Presiden No. 174 Tahun 1999 tentang Remisi; Keputusan Menteri Hukum dan Perundangundangan RI No. M.09.HN.02.01 Tahun 1999 tentang Pelaksanaan Keputusan Presiden No. 174 Tahun 1999; Keputusan Menteri Hukum dan Perundang-undangan No. M.10.HN.02.01 Tahun 1999 tentang Pelimpahan Wewenang Pemberian Remisi Khusus; Keppres RI No. 120 Tahun 1995 tentang Ampunan Istimewa; Kep. Menteri Kehakiman RI No. 04.HN.02.01 Tahun 1988 tentang Tambahan Remisi Bagi Narapidana yang Menjadi Donor Organ Tubuh dan Donor Darah; Surat Edaran No. E.PS.01-03-15 tanggal 26 Mei 2000 tentang Perubahan Pidana Penjara Seumur Hidup Menjadi Pidana Penjara Sementara; dan Pelaksanaan pemberian remisi terhadap narapidana di Lapas berdasarkan peraturan yang berlaku yaitu UndangUndang No. 12 Tahun 1995 dan PP No. 28 Tahun 2006 berupa Remisi Umum dan Remisi Khusus.

\section{Rekomendasi}

Pengaturan remisi yang merupakan hak narapidana perlu diadakan peraturan yang lebih kuat berupa Keputusan Menkumham sebagai pembaharuan keputusan sebelumnya dan tidak berupa Surat Edaran; dan Pelaksanaan pemberian remisi terhadap narapidana perlu diperjelas pedomannya untuk menghindari terjadinya penyelewengan mengenai pengajuan remisi, baik untuk di Lapas maupun Depkumham.

\section{DAFTAR PUSTAKA}

\section{Peraturan Perundang-undangan:}

Undang-Undang Nomor 12 Tahun 1995 tentang Pemasyarakatan.

Peraturan Pemerintah RI Nomor 31 Tahun 1999 tentang Pembinaan dan Pembimbingan Warga Binaan Pemasyarakatan.
Peraturan Pemerintah RI Nomor 32 Tahun 1999 tentang Syarat dan Tatacara Pelaksanaan Hak Warga Binaan Pemasyarakatan.

Peraturan Pemerintah RI Nomor 28 Tahun 2006 tentang Perubahan atas Peraturan Pemerintah RI Nomor 32 Tahun 1999 tentang Syarat dan Tata Cara Pelaksanaan Hak Warga Binaan Pemasyarakatan.

Peraturan Pemerintah RI Nomor 99 Tahun 2012 tentang Perubahan Kedua atas Peraturan Pemerintah RI Nomor 32 Tahun 1999 tentang Syarat dan Tatacara Pelaksanaan Hak Warga Binaan Pemasyarakatan.

Keputusan Presiden RI Nomor 120 Tahun 1995 tentang Ampunan Istimewa.

Keputusan Presiden RI Nomor 174 Tahun 1999 tentang Remisi.

Keputusan Menteri Kehakiman RI Nomor 04.HN.02.01 Tahun 1988 tentang Tambahan Remisi Bagi Narapidana yang Menjadi Donor Organ Tubuh dan Donor Darah.

Keputusan Menteri Kehakiman Nomor M.02. PK.02.01 Tahun 1999 tentang Pola Pembinaan Narapidana/Tahanan.

Keputusan Menteri Hukum dan Perundang-undangan RI Nomor M.09.HN.02.01 Tahun 1999 tentang Pelaksanaan Keputusan Presiden Nomor 174 Tahun 1999.

Keputusan Menteri Hukum dan Perundang-undangan Nomor M.10.HN.02.01 Tahun 1999 tentang Pelimpahan Wewenang Pemberian Remisi Khusus.

Surat Edaran Nomor E.PS.01-03-15 tanggal $26 \mathrm{Mei}$ 2000 tentang Perubahan Pidana Penjara Seumur Hidup Menjadi Pidana Penjara Sementara.

\section{Buku:}

Amiruddin dan H. Zainal Asikin. 2003. Pengantar Metode Penelitian Hukum. Jakarta: Raja Grafindo.

Poerwadarminta, W.J.S. 1990. Kamus Besar Bahasa Indonesia. Jakarta: Balai Pustaka.

Priyanto, Dwija. 2006. Sistem Pelaksanaan Pidana Penjara di Indonesia. Bandung: Refika Aditama. Soemitro, Ronny Hanitijo. 1982. Metodologi Penelitian Hukum. Semarang: Ghalia Indonesia. 